\title{
SEKOLAH KEJURUAN SEBAGAI CORPORATE SOCIAL RESPONSIBILITY DJARUM FOUNDATION
}

\author{
Dede Sulaeman, Leila Mona \\ Magister Ilmu Komunikasi Komunikasi Universitas Mercu Buana \\ desulanakata@gmail.com, leila.mona@mercubuana.ac.id \\ Diajukan: 17-11-2017; Direview: 17-11-2017; Diterima: 22-12-2017;
}

\begin{abstract}
PT. Djarum is able to stand and operate its business for many years amid tight competition of cigarette business and rapid pressures from both public and government policies. It clearly requires company's ability to run a series of reliable strategies. This study aims to determine the eminence of the Djarum Foundation Vocational School program, its communication, and community's legitimacy of the program. Using qualitative descriptive approach with the constructivist paradigm, this research utilizes interview and literature study as the data collection technique, while case study is applied as its study design. The results of this study explain that the Vocational School program is a superior CSR program, not easily imitated, and achieves the level of sustaining survival. Communications of Vocational School Program are conducted effectively by selecting media, targets, message contents, and resource persons in accordance with the program and the products it produces.
\end{abstract}

Keyword: CSR, Vocational School, Legitimacy, Sustaining Survival

\begin{abstract}
Abstrak
Beroperasi di tengah ketatnya persaingan bisnis rokok, derasnya tekanan masyarakat maupun kebijakan pemerintah Djarum membutuhkan strategi bisnis yang kreatif. Program CSR Djarum Foundation dalam bentuk Program Sekolah Kejuruan (Vocational School) dipercaya menjadi salah satu strategi korporasi dalam upaya untuk bertahan bahkan mengembangkan bisnis. Penelitian ini bertujuan untuk mengetahui keunggulan program Sekolah Kejuruan Djarum Foundation, strategi komunikasi, dan legitimasi masyarakat terhadap program. Penelitian deskriptif kualitatif ini mengumpulkan data melalui wawancara dan studi kepustakaan. Hasil penelitian menjelaskan bahwa Sekolah Kejuruan merupakan program CSR yang unggul, tidak mudah ditiru, dan berhasil mencapai tahap sustaining survival. Komunikasi program Sekolah Kejuruan dilakukan dengan pemilihan media, sasaran, isi pesan, dan narasumber secara efektif. Pendekatan tersebut menguatkan posisi strategis Djarum Foundation di level nasional dan internasional. Sekolah Kejuruan Djarum juga memperoleh legitimasi yang tercermin dari antusiasme masyarakat terhadap program; meningkatkan ekonomi masyarakat Kudus; dan apresiasi pemerintah baik daerah maupun pusat.
\end{abstract}

Kata Kunci: CSR, Sekolah Kejuruan, Legitimasi, Sustaining Survival

\section{PENDAHULUAN}

$\mathrm{P}$ T. Djarum yang sudah berdiri kokoh selama bertahun-tahun memiliki kemampuan mempertahankan diri (survival) di tengahtengah persaingan bisnis rokok yang sedemikian kencang, ditambah dengan banyaknya kalangan yangkontrakarenaproduknya yang membahayakan kesehatan. Daya survival tersebut diperoleh dari banyak hal yang telah dimiliki dan dilakukan oleh PT. Djarum, salah satunya dari sisi social responsibility. PT Djarum telah melaksanakan program Corporate Social Responsibility selama bertahun-tahun dan mendapat pengakuan serta penghargaan. Daya survival PT. Djarum tersebut harus terus dirawat dan dikuatkan, karena industri rokok tergolong ke dalam industri yang banyak mendapat protes dari publik. Fakta-fakta menunjukkan bahwa industri rokok mengahadapi 
banyak ancaman, terutama dari sisi reputasi. Tak dapat disangkal, industri rokok menjadi musuh bersama, karena ia dianggap sebagai sumber masalah kesehatan masyarakat. Ancaman terhadap reputasi perusahaan rokok begitu gencar dan berasal dari berbagai pihak, mulai dari LSM sampai pemerintah yang mempunyai kekuatan kebijakan yang berlangsung terus menerus.

Melihat fakta-fakta ancaman terhadap perusahaan rokok yang sedemikian besar, maka industri rokok berada dalam kesulitan untuk mempertahankan eksistensinya. Oleh karena itu, perusahaan rokok harus melakukan upaya-upaya strategis sehingga keberlangsungan perusahaan dan semua aktivitas bisnisnya dapat terus terjaga. Salah satu upaya yang dilakukan oleh banyak perusahaan rokok untuk mempertahankan eksistensi adalah dengan menjalankan Corporate Social Responsibility (CSR). Tujuannya supaya perusahaan rokok tetap mendapatkan penerimaan (legitimasi) masyarakat dan supaya mereka dapat mempertahankan eksistensi (sustaining survival) di tengah banyaknya tekanan dan pembatasan oleh banyak pihak. CSR industri rokok memiliki keterbatasan, sehingga menjadi tantangan tersendiri bagi perusahaan rokok dalam mengembangkan kegiatan CSR. Dalam hal ini, perusahaan rokok harus menggerakkan semua sumber daya CSR-nya untuk membuat dan menjalankan program CSR yang besar, unik, tidak mudah ditiru oleh yang lain, dan bermanfaat bagi masyarakat, terutama masyarakat di mana perusahaan tersebut berdiri dan menjalankan bisnisnya. Dalam konteks perusahaan rokok, tujuan dilaksanakannya CSR harus diturunkan levelnya pada upaya mendapatkan penerimaan (legitimasi) masyarakat dan mempertahankan eksistensi (sustaining survival), karena banyaknya tekanan dan pembatasan oleh berbagai pihak. Pallazo dan Richter (2005: 393) menjelaskan bahwa CSR yang dilakukan oleh industri rokok lebih bertujuan untuk memperjuangkan eksistensi mereka.

Sejak 2012 Djarum Foundation telah menjalankan program Peningkatan Kualitas Sekolah Menengah Kejuruan yang selaras dengan rumusan pemerintah. Kementerian Pendidikan dan Kebudayaan merumuskan Sekolah Menengah
Kejuruan (SMK) dan langkah revitalisasinya, untuk menciptakan sumber daya manusia unggul di setiap bidang serta memiliki daya saing. Hal itu sesuai dengan rumusan Inpres Nomor 9 Tahun 2016 tentang Revitalisasi Sekolah Menengah Kejuruan. Ada sepuluh langkah revitalisasi, yaitu: revitalisasi sumber daya manusia; membangun SAS berbasis Sistem Informasi Manajemen (SIM); link and match dengan industri; kurikulum berbasis industri; teaching factory; penggunaan Media Video Tutorial dan Portofolio Berbasis Video e-Report Skill; Uji Sertifikasi Profesi; pemenuhan sarana dan prasarana; mengembangkan Kearifan Lokal; dan peran SMK Sebagai Penggerak Ekonomi Lokal (Hadam, Rahayu, dan Ariyadi, 2017: 21-180). Jurusan yang dikembangkan Djarum Foundation berfokus pada jurusan yang memiliki potensi permintaan sumber daya manusia pada bidang pekerjaan berpenghasilan tinggi, seperti bidang teknologi informasi, penerapan kurikulum Cisco Networking Academy Program (CNAP) di SMK jurusan Teknik Komputer dan Jaringan yang bertujuan meningkatkan lulusan terampil dengan sertifikasi yang diakui seluruh dunia. Sehingga, selain selaras dengan rumusan Inpres Nomor 9 Tahun 2016, Sekolah Kejuruan yang dikembangkan Djarum Foundation juga memiliki keunggulan dari aspek kualitas. SMK jurusan Teknik Mesin bekerja sama dengan institusi dari Jerman dalam program pengembangan kurikulum dan pengoperasian peralatan canggih untuk praktikum siswa. Di bidang kelautan, SMK Wisudha Karya menjadi satu-satunya sekolah pelayaran tingkat SMK di Indonesia yang memiliki fasilitas full mission bridge simulator. Melalui paket keahlian Nautika Kapal Niaga, sekolah ini mempersiapkan perwira muda di bidang navigasi kapal niaga. Paket keahlian lain yang juga dikembangkan di bidang kelautan ialah Teknika Kapal Niaga. Dilengkapi dengan ruang mesin kapal, para calon perwira muda disiapkan untuk menjadi ahli permesinan kapal niaga. Lulusan dari masingmasing paket keahlian tersebut akan memperoleh Certificate of Competency Class 4 yang diakui dunia internasional. Di bidang ekonomi kreatif, ada tiga jurusan yang dikembangkan, yaitu Tata Boga, Tata Busana, dan Animasi. Jurusan Tata 
Boga menerapkan kurikulum yang mewajibkan para siswa untuk sanggup menguasai minimal 30 ikon kuliner tradisional Indonesia. Jurusan Tata Busana menerapkan kurikulum perancangan busana menggunakan berbagai kain tradisional Nusantara. Selain itu, para siswa program Sekolah Menengah Kejuruan binaan Djarum Foundation (selanjutnya ditulis Sekolah Kejuruan) sudah banyak yang berprestasi di tingkat nasional dan internasional, bahkan sebelum mereka lulus. Dengan melihat program Sekolah Kejuruan Djarum Foundation yang unik, berkualitas, tidak mudah ditiru, dan bermanfaat bagi peningkatan kualitas sumberdaya manusia yang siap pakai dengan standar internasional, dapat dikatakan bahwa program tersebut berpotensi menjadi sumber daya perusahaan untuk mempertahankan eksistensi perusahaan. Penelitian ini bertujuan untuk mengetahui komunikasi program Sekolah Kejuruan sebagai pelopor pengembangan CSR bidang pendidikan dan mengetahui pencapaian program terhadap legitimasi masyarakat dan sustaining survival perusahaan.

\section{LITERATUR DAN METODOLOGI}

Tanggung jawab sosial korporasi adalah suatu filsafat etika bisnis dimana semua kepentingan korporasi dibuat sepenuhnya dengan menghargai dan memerhatikan hak-hak asasi manusia. Kotler dan Nancy (2005: 4) mendefinisikan Corporate Social Responsibility sebagai tanggung jawab sosial perusahaan adalah sebuah komitmen untuk mengembangkan kesejahteraan masyarakat melalui praktik bisnis mengikuti pertimbangan sendiri dan kontribusi sumber-sumber perusahaan. Program CSR merupakan komitmen perusahaan untuk mendukung terciptanya pembangunan berkelanjutan (sustainable development), di samping sebagai komitmen moral perusahaan untuk membangun masyarakat lokal (Ingratubun, 2017: 86).

Carroll (1991: 39) mengemukakan satu konsep Piramida Tanggung Jawab Sosial Perusahaan yang terdiri atas empat jenjang tanggung jawab sosial perusahaan: tanggung jawab ekonomi, tanggung jawab hukum, tanggung jawab etika, dan tanggung jawab kedermawanan. Selain itu, menurut Ganiem, Ambadar, dan Sukardjo, ada pula kedermawanan yang sifatnya personal, yaitu Personal Social Responsibility (PSR). PSR merupakan wujud dari tanggung jawab individu kepada masyarakat karena ia bagian dari masyarakat (Ganiem, Ambadar, dan Sukardjo, 2015). PSR adalah sebuah ide personal dari Corporate Social Responsibility (CSR). Corporate Social Responsibility yang dilaksanakan oleh perusahaan rokok banyak mendapatkan kritik dari pihak yang kontra, karena produk rokok dapat membahayakan kesehatan. Badan kesehatan dunia WHO mempertanyakan kegiatan CSR yang dilakukan oleh industri rokok dan mengkategorikannya sebagai 'inherent contradiction' (Palazzo dan Richter, 2005: 388). Bertolak belakang dengan produknya yang membahayakan, ternyata banyak perusahaan rokok besar yang secara masif melakukan kegiatan CSR, termasuk di Indonesia. Hal itu dilakukan dengan tujuan supaya mereka (industri rokok) tetap mendapatkan penerimaan (legitimasi) masyarakat dan supaya mereka dapat mempertahankan eksistensi (sustaining survival) di tengah banyaknya tekanan dan pembatasan oleh banyak pihak. Menegaskan ini, Pallazo dan Richter (2005: 393) menjelaskan bahwa CSR yang dilakukan oleh industri rokok lebih bertujuan untuk memperjuangkan eksistensi mereka.

Karena banyak pihak yang menolak dan mengkritik industri rokok, CSR industri rokok memiliki keterbatasan, sehingga menjadi tantangan tersendiri bagi perusahaan rokok dalam mengembangkan kegiatan CSR. Keterbatasan yang dihadapi perusahaan rokok dalam menjalankan CSR, dijelaskan oleh Palazzo dan Richter (2005: 390-393), yaitu: Corporate Philantrophy, Stakeholder Collaboration, CSR Reporting, dan Self Regulation. Sebuah program yang baik, jika tidak dikomunkasikan dengan baik, maka hasilnya tidak akan maksimal. Karena itu, diperlukan strategi komunikasi agar tanggung jawab sosial perusahaan memperoleh pandangan positif dari komunitas dan keberadaan perusahaan dirasakan manfaatnya oleh masyarakat. Hardjana (2008: 7) mengasumsikan bahwa seluruh komunikasi dikembangkan dengan mengaitkannya dengan strategi dasar dari perusahaan. Artinya, setiap organisasi tergantung pada konstituensi (constituencies), yakni berbagai kelompok kepentingan yang mendukung kelangsungan 
hidup organisasi. Strategi komunikasi perusahaan merupakan hal penting dalam mengelola kondisi lingkungan yang tidak pasti, baik untuk mencegah situasi krisis, maupun ketika perusahaan sedang mengalami situasi krisis (Sabini dan Ganiem, 2015: 347).

Dalam melaksanakan strategi komunkasi terdapat komponen-komponen yang menjadi bahan pertimbangan, yaitu komunikator, tujuan, isi pesan, media komunikasi, dan komunikan. Media komunikasi saat ini lebih banyak menggunakan media massa karena ia menimbulkan keserempakan. Iklan yang memberikan informasi mengenai atribut Corporate Social Responsibility dapat digunakan untuk membangun dan mempertahankan reputasi untuk kualitas, keandalan, dan kejujuran (Mc. Williams at. al., 2001). Kegiatan periklanan harus ditayangkan melalui media yang sesuai dengan karakteristik khalayak sasaran, sehingga pesan dapat menjangkau khalayak secara efektif dengan biaya yang paling efisien (Restiyanti, 2016: 137). Semua perusahaan atau organisasi selalu mempertimbangkan legitimasi dari para pemangku kepentingan (stakeholders) dalam setiap aktivitas yang dilakukannya. Legitimasi adalah penyesuaian terhadap norma, nilai, dan ekspektasi sosial (Ekawati (2012: 21). Secara personal, legitimasi atas suatu tindakan atau institusi diperoleh dan dianggap berasal dari konstruksi sosial (Berger dan Luckmann, 1966 dalam Ekawati, 2012: 21). Menurut Palazzo dan Scherer (2006) dalam Ekawati (2012: 21) legitimasi juga berperan penting bagi perusahaan yang beroperasi dalam lingkup global. Menurut Suchman (1995) dalam Ekawati (2012), ada 3 (tiga) bentuk legitimasi dalam organisasi, yaitu:
Pragmatic Legitimacy, Cognitive Legitimacy, dan Moral Legitimacy.

Penelitian ini menggunakan metode deskriptifinterpretif yang menjelaskan fenomena yang diteliti apa adanya. Menurut Daymon dan Holloway (2008: 6) penelitian yang menggunakan paradigma interpretif menentang gagasan bahwa realitas sosial adalah sesuatu yang kita terima begitu saja, sesuatu "dari luar sana" yang membentuk tindakan masyarakat. Locke sebagaimana dikutip Daymon dan Holloway (2008) menjelaskan, peneliti interpretif meyakini teori konstruktivisme sosial ( $\mathrm{so}$ cial constructivism). Penelitian ini menerapkan studi kasus sebagai desain penelitiannya. Teknik pengumpulan data dilakukan dengan menggunakan wawancara dan studi kepustakaan. Wawancara dilakukan kepada Direktur Program Djarum Bakti Pendidikan dan Assocciate program tersebut.

\section{TEMUAN DAN DISKUSI}

Hasil penelitian ini menjelaskan bahwa Sekolah Kejuruan Djarum Foundation merupakan program CSR yang unggul, tidak mudah ditiru, dan berhasil mencapai tahap sustaining survival. Berdasarkan Uji VRINE program ini sudah mencapai sustaining survival. Capaian ini akan bertahan lama, karena lembaga lain tidak akan mudah untuk meniru program tersebut. Kenapa tidak mudah ditiru? Karena program tersebut adalah pelopor, dan berstandar internasional. Untuk menirunya, dibutuhkan SDM yang bagus dan biaya yang besar, pengalaman, networking, serta kepercayaan dari stakeholders lain. Capaian sustaining survival tersebut sebagaimana dijelaskan dalam tabel 1.

Tabel 1. Uji VRINE Program Vocational School

\begin{tabular}{|c|c|c|}
\hline Uji VRINE & Implication Kompetitif & Implikasi Performasi \\
\hline \multicolumn{3}{|l|}{ Is it valuable? } \\
\hline 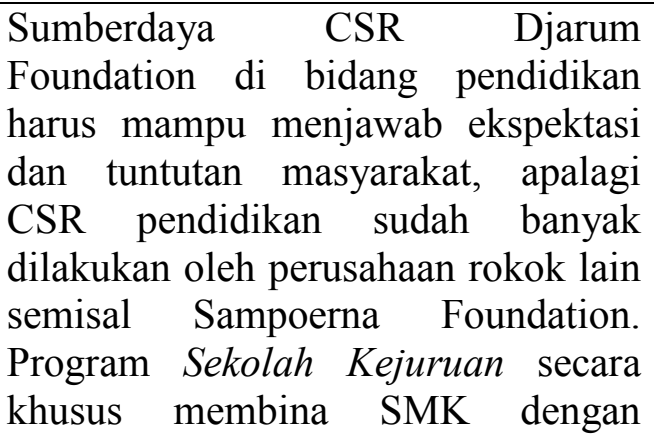 & $\begin{array}{lr}\text { Program } & \text { Sekolah } \\
\text { Kejuruan } & \text { menjadi } \\
\text { sumberdaya } & \text { CSR } \\
\text { Djarum Foundation di } & \text { didang pendidikan. }\end{array}$ & $\begin{array}{lr}\text { Keberhasilan } & \text { Program } \\
\text { Sekolah } & \text { Kejuruan } \\
\text { ditentukan oleh kualitas } \\
\text { para siswa SMK binaan } \\
\text { Djarum } \\
\text { tersebut. }\end{array}$ \\
\hline
\end{tabular}


fasilitas, kurikulum, dan sistem pengajaran berstandar internasional.

\begin{tabular}{|c|c|c|}
\hline \multicolumn{3}{|l|}{ Is it rare? } \\
\hline $\begin{array}{l}\text { Setidaknya sampai sekarang belum } \\
\text { ada program CSR di bidang } \\
\text { pendidikan yang menyamai Program } \\
\text { Sekolah Kejuruan. }\end{array}$ & $\begin{array}{lr}\text { Dengan } & \text { demikian } \\
\text { Djarum } & \text { Foundation } \\
\text { dapat meraih } & \text { Survival } \\
\text { yang } & \text { sifatnya } \\
\text { sementara. } & \end{array}$ & $\begin{array}{l}\text { Survival yang sudah } \\
\text { diraih Djarum } \\
\text { Foundation baru bersifat } \\
\text { sementara, sampai ada } \\
\text { CSR perusahaan lain } \\
\text { yang membuat program } \\
\text { pembinaan SMK yang } \\
\text { sama dengan Program } \\
\text { Sekolah Kejuruan. }\end{array}$ \\
\hline \multicolumn{3}{|l|}{ Is it inimitable/ nonsubstitutable? } \\
\hline $\begin{array}{l}\text { Program Sekolah Kejuruan sulit } \\
\text { untuk ditiru dari sisi konsep dan } \\
\text { praktik. Dari sisi konsep yang } \\
\text { berstandar dan bersertifikasi } \\
\text { internasional, diperlukan sumberdaya } \\
\text { yang mumpuni untuk membuat } \\
\text { program serupa itu. Sementara dari } \\
\text { sisi praktik dibutuhkan waktu dan } \\
\text { pengalaman sendiri untuk } \\
\text { mewujudkan program serupa. }\end{array}$ & $\begin{array}{lr}\text { Dengan } & \text { demikian } \\
\text { Djarum } & \text { Foundation } \\
\text { sudah } & \text { mencapai } \\
\text { Sustaining } & \text { Survival } \\
\text { dalam CSR } & \text { bidang } \\
\text { pendidikan } & \text { untuk } \\
\text { Program } & \text { Sekolah } \\
\text { Kejuruan. } & \end{array}$ & $\begin{array}{lr}\text { Program } & \text { Sekolah } \\
\text { Kejuruan } & \text { dapat } \\
\text { memberikan } & \text { long-term } \\
\text { sustainability } & \text { bagi } \\
\text { Djarum Foundation di } \\
\text { bidang pendidikan. }\end{array}$ \\
\hline
\end{tabular}

\begin{tabular}{l} 
Is it exploitable? \\
\hline Program Sekolah Kejuruan yang \\
dilaksanakan Djarum Foundation \\
telah dimulai sejak tahun 2012. \\
Dengan konsep yang terstandar \\
internasional program ini telah \\
dilaksanakan dan menghasilkan \\
prestasi di ajang internasional. \\
Berikut adalah beberapa hasil dari \\
penerapan program tersebut:
\end{tabular}

Pada 13-19 Oktober 2015, tiga murid terbaik dari Program Sekolah Kejuruan pada bidang keahlian Culinary Art, yaitu Afifah Ramadhani, Billa Prilia Putri, dan Yoga Bayu Sadewa, dipilih sebagai tim kuliner Indonesia di ajang bergengsi dunia, Frankfurt Book Fair 2015.

Pada tahun 2016, empat siswi program tersebut diterjunkan pada acara kuliner di Tokyo yang salah satu rangkaiannya adalah gala dinner
Konsep kurikulum, Beberapa siswa program fasilitas, dan sistem Sekolah Kejuruan yang pengajaran Program telah mengukir prestasi Sekolah Kejuruan ini dan dikenal masyarakat berhasil diterapkan luas karena oleh Djarum dipublikasikan di media Foundation. Hal itu massa, yaitu Afifah dibuktikan dengan Ramadhani, Billa Prilia prestasi para siswa Putri, dan Yoga Bayu hasil didikan program Sadewa (bidang tersebut pada tingkat keahlian Culinary Art); nasional dan Muhammad Daanni internasional. Prestasi- Irsyaad (bidang keahlian prestasi tersebut belum Computer and Network dimiliki oleh CSR Engineering); Risa perusahaan lain di Maharani, Nafida bidang pendidikan, Royyana, Nia Faradiska, khususnya program dan Rania (bidang pembinaan sekolah keahlian Fashion kejuruan. Design). 
peluncuran Indonesian Culinary Fair Tokyo 2016 bersama KBRI Tokyo yang dihadiri oleh Her Royal Highness Princess Takamado dan Dr. Yukio Hattori, President Hattori Nutrition College.

Pada tahun 2016, salah satu siswa SMK program Djarum Foundation, Muhammad Daanni Irsyaad berhasil menjadi juara pertama pada kompetisi Cisco Networking Academy Netriders Asia Pasifik dan Jepang 2016 yang digelar pada 15 September di Indonesia. Cisco Networking Academy Netriders Asia Pasifik dan Jepang 2016 diikuti lebih dari 400 peserta dari sembilan negara yaitu Australia, Indonesia, India, Kamboja, Srilanka, Malaysia, Filipina, Singapura dan Thailand.

Pada tahun 2016, Sekolah Kejuruan juga berhasil membawa empat siswanya untuk menduduki peringkat 10 besar. Tidak hanya sukses merebut posisi teratas pada ajang bergengsi ini, tetapi para siswa itu juga berhasil mengungguli lawan yang datang dari perguruan tinggi terbaik se-Asia Pasifik. Hal itu menunjukkan bahwa siswa SMK hasil binaan Djarum Foundation mampu bersaing dengan mahasiswa perguruan tinggi setingkat Asia Pasifik.

Pada September 2016, empat siswi Sekolah Kejuruan berkesempatan memamerkan hasil karya rancangannya di ajang internasional, Asia's Fashion Spotlight di Hong Kong. Keempat siswi dimaksud adalah Risa Maharani, Nafida Royyana, Nia Faradiska, dan Rania. Mereka bisa menembus pasar internasional setelah mengikuti program Sekolah Kejuruan pada bidang keahlian Fashion. 
Bekerjasama dengan Indonesia Fashion Chamber (IFC), para siswi tersebut dilatih supaya bisa menjadi desainer fashion kelas dunia.

Pada 24 Februari 2017, film animasi 3D, Pasoa dan Sang Pemberani diputar perdana di layar bioskop CGV Cinemas Grand Indonesia. Film yang mengangkat kisah dan karakter asli Nusantara itu karya para pelajar SMK Raden Umar Said, binaan Djarum Foundation. Tidak kurang dari 38 siswa kelas X-XII di sekolah tersebut terlibat langsung dalam proses pembuatan film animasi besutan RUS Animation Studio. Menurut Technical Advisor RUS Animation Studio Daniel Harjanto, film berdurasi 25 menit tersebut prosesnya sangat rumit, tapi meski dikerjakan para pelajar tingkat SMK, hasilnya sesuai dengan standar industri animasi profesional. Setelah dipemutar di bioskop CGV Cinemas Grand Indonesia, film itu juga ditayangkan di televisi swasta SCTV pada 4 Maret 2017.

\section{Sumber: Hasil Olahan Sendiri}

Program Sekolah Kejuruan Djarum Foundation sulit untuk ditiru dari sisi konsep dan praktik. Dari sisi konsep yang berstandar dan bersertifikasi internasional, diperlukan sumberdaya yang mumpuni untuk membuat program serupa itu. Sementara dari sisi praktik dibutuhkan waktu dan pengalaman sendiri untuk mewujudkan program serupa Program Sekolah Kejuruan.

Tabel 2. Sepuluh Bidang Keahlian Program Sekolah Kejuruan

\begin{tabular}{|c|c|c|c|c|c|c|c|c|}
\hline \multirow[t]{2}{*}{$\begin{array}{l}\text { Program } \\
\text { Keahlian }\end{array}$} & \multicolumn{5}{|c|}{ Jumlah Siswa yang Terdaftar } & \multirow[t]{2}{*}{$\begin{array}{l}\text { Sekolah yang } \\
\text { Berpartisipasi }\end{array}$} & \multirow{2}{*}{$\begin{array}{l}\text { Target } \\
\text { Gaji } \\
\text { Lulusan }\end{array}$} & \multirow[t]{2}{*}{$\begin{array}{l}\text { Pihak yang } \\
\text { Bekerjasama }\end{array}$} \\
\hline & $\begin{array}{l}2012 / \\
2013\end{array}$ & $\begin{array}{l}2013 / \\
2014\end{array}$ & $\begin{array}{l}2014 / \\
2015\end{array}$ & $\begin{array}{l}2015 / \\
2016\end{array}$ & $\begin{array}{l}2016 / \\
2017\end{array}$ & & & \\
\hline $\begin{array}{l}\text { Computer } \\
\text { and Network } \\
\text { Engineering }\end{array}$ & 1.271 & 1.466 & 1.696 & 2.179 & 2.681 & $\begin{array}{l}\text { SMK } \\
\text { Assaidiyyah } \\
\text { Kudus, SMK } \\
\text { Muhammadiya } \\
\text { h Kudus, SMK } \\
\text { NU Maarif } \\
\text { Kudus, SMKN } \\
3 \text { Kudus }\end{array}$ & $\begin{array}{l}5 \text { s.d. } 6 \\
\text { juta } \\
\text { rupiah } \\
\text { per bulan }\end{array}$ & $\begin{array}{l}\text { Cisco } \\
\text { Networking } \\
\text { Academy } \\
\text { Program } \\
\text { (CNAP) }\end{array}$ \\
\hline $\begin{array}{l}\text { Mechanical } \\
\text { Engineering }\end{array}$ & 1.245 & 1.357 & 1.484 & 1.745 & 1.926 & $\begin{array}{l}\text { SMK Wisudha } \\
\text { Karya Kudus, }\end{array}$ & $\begin{array}{l}7 \text { s.d. } 8 \\
\text { juta }\end{array}$ & $\begin{array}{l}\text { Politeknik } \\
\text { ATMI }\end{array}$ \\
\hline
\end{tabular}




\begin{tabular}{|c|c|c|c|c|c|c|c|c|}
\hline & & & & & & $\begin{array}{l}\text { SMK K. } \\
\text { Nusantara } \\
\text { Kudus, dan } \\
\text { SMK NU } \\
\text { Maarif Kudus }\end{array}$ & $\begin{array}{l}\text { rupiah } \\
\text { per bulan }\end{array}$ & Surakarta \\
\hline $\begin{array}{l}\text { Culinary } \\
\text { Arts }\end{array}$ & 36 & 147 & 278 & 404 & 481 & $\begin{array}{l}\text { SMKN 1 } \\
\text { Kudus, SMK } \\
\text { PGRI 2 Kudus, } \\
\text { dan SMK } \\
\text { Assaidiyah } \\
\text { Kudus }\end{array}$ & $\begin{array}{l}8 \text { s.d. } 10 \\
\text { juta } \\
\text { rupiah } \\
\text { per bulan }\end{array}$ & $\begin{array}{l}\text { William } \\
\text { Wongso dan } \\
\text { Sekolah } \\
\text { Kuliner Dapur } \\
\text { Nusantara } \\
\text { BNI (Kudapan } \\
\text { BNI) }\end{array}$ \\
\hline $\begin{array}{l}\text { Fashion } \\
\text { Design }\end{array}$ & 641 & 674 & 634 & 732 & 883 & $\begin{array}{l}\text { SMKN NU } \\
\text { Banat Kudus, } \\
\text { SMKN 1 } \\
\text { Kudus, dan } \\
\text { SMKN } 3 \\
\text { Kudus }\end{array}$ & $\begin{array}{l}7 \text { s.d. } 9 \\
\text { juta } \\
\text { rupiah } \\
\text { per bulan }\end{array}$ & $\begin{array}{l}\text { Indonesia } \\
\text { Fashion } \\
\text { Chamber } \\
\text { (IFC) }\end{array}$ \\
\hline $\begin{array}{l}\text { Nautical } \\
\text { Studies }\end{array}$ & - & - & 30 & 87 & 205 & $\begin{array}{l}\text { SMK Wisudha } \\
\text { Karya Kudus }\end{array}$ & $\begin{array}{l}12 \text { s.d. } 14 \\
\text { juta } \\
\text { rupiah } \\
\text { per bulan }\end{array}$ & $\begin{array}{l}\text { PT Bank } \\
\text { Sumitomo } \\
\text { Mitsui } \\
\text { Indonesia } \\
\text { (SMBCI)- } \\
\text { Sumitomo } \\
\text { Mitsui } \\
\text { Banking } \\
\text { Corporation } \\
\text { (SMBC), } \\
\text { Jepang dan } \\
\text { ITE Education } \\
\text { Services } \\
\text { (ITEES), } \\
\text { Singapura }\end{array}$ \\
\hline $\begin{array}{l}\text { Marine } \\
\text { Engineering }\end{array}$ & - & - & 30 & 81 & 141 & $\begin{array}{l}\text { SMK Wisudha } \\
\text { Karya Kudus }\end{array}$ & $\begin{array}{l}12 \text { s.d. } 14 \\
\text { juta } \\
\text { rupiah } \\
\text { per bulan }\end{array}$ & $\begin{array}{l}\text { PT Bank } \\
\text { Sumitomo } \\
\text { Mitsui } \\
\text { Indonesia } \\
\text { (SMBCI)- } \\
\text { Sumitomo } \\
\text { Mitsui } \\
\text { Banking } \\
\text { Corporation } \\
\text { (SMBC), } \\
\text { Jepang; } \\
\text { TANN Group } \\
\text { Catharina } \\
\text { Trierenberg, } \\
\text { Austria; dan } \\
\text { ITE Education } \\
\text { Services } \\
\text { (ITEES), } \\
\text { Singapura }\end{array}$ \\
\hline
\end{tabular}




\begin{tabular}{|c|c|c|c|c|c|c|c|c|}
\hline Animation & - & - & 30 & 25 & 92 & $\begin{array}{l}\text { SMK Wisudha } \\
\text { Karya Kudus }\end{array}$ & $\begin{array}{l}6 \text { s.d. } 7 \\
\text { juta } \\
\text { rupiah } \\
\text { per bulan }\end{array}$ & $\begin{array}{l}\text { PT Bank } \\
\text { Sumitomo } \\
\text { Mitsui } \\
\text { Indonesia } \\
\text { (SMBCI)- } \\
\text { Sumitomo } \\
\text { Mitsui } \\
\text { Banking } \\
\text { Corporation } \\
\text { (SMBC), } \\
\text { Jepang }\end{array}$ \\
\hline $\begin{array}{l}\text { Software } \\
\text { Engineering }\end{array}$ & - & - & 39 & 128 & 284 & $\begin{array}{l}\text { SMK Raden } \\
\text { Umar Said } \\
\text { Kudus }\end{array}$ & $\begin{array}{l}6 \text { s.d. } 7 \\
\text { juta } \\
\text { rupiah } \\
\text { per bulan }\end{array}$ & $\begin{array}{l}\text { Oracle } \\
\text { Certified } \\
\text { Associate } \\
\text { (OCA) dan } \\
\text { BINUS Center }\end{array}$ \\
\hline $\begin{array}{l}\text { Visual } \\
\text { Communic } \\
\text { ations }\end{array}$ & - & 34 & 66 & 91 & 93 & $\begin{array}{l}\text { SMK Raden } \\
\text { Umar Said } \\
\text { Kudus }\end{array}$ & $\begin{array}{l}6 \text { s.d. } 7 \\
\text { juta } \\
\text { rupiah } \\
\text { per bulan }\end{array}$ & $\begin{array}{l}\text { PT Bank } \\
\text { Sumitomo } \\
\text { Mitsui } \\
\text { Indonesia } \\
\text { (SMBCI)- } \\
\text { Sumitomo } \\
\text { Mitsui } \\
\text { Banking } \\
\text { Corporation } \\
\text { (SMBC), } \\
\text { Jepang }\end{array}$ \\
\hline $\begin{array}{l}\text { Architectur } \\
\text { al Drafting }\end{array}$ & - & 53 & 86 & 98 & 145 & $\begin{array}{l}\text { SMK } \\
\text { Nusantara } \\
\text { Kudus dan } \\
\text { SMK Lemuria } \\
\text { Kudus }\end{array}$ & $\begin{array}{l}4 \text { s.d. } 6 \\
\text { juta } \\
\text { rupiah } \\
\text { per bulan }\end{array}$ & $\begin{array}{l}\text { PT Bank } \\
\text { Sumitomo } \\
\text { Mitsui } \\
\text { Indonesia } \\
\text { (SMBCI)- } \\
\text { Sumitomo } \\
\text { Mitsui } \\
\text { Banking } \\
\text { Corporation } \\
\text { (SMBC), } \\
\text { Jepang }\end{array}$ \\
\hline
\end{tabular}

Sumber: Booklet Vocational School Djarum Foundation 2017

Meskipun capaian Sustaining Survival tersebut dapat bertahan lama, Djarum Foundation tetap harus melakukan inovasi-inovasi dan terus menggali potensi-potensi baru melalui membangun sekolah-sekolah kejuruan dengan bidang keahlian yang belum ada. Dengan cara ini memungkinkan Djarum Foundation untuk tetap mempertahankan Sustaining Survival perusahaan secara berkelanjutan. Oleh karena itu, Djarum Foundation terus berupaya mempertahankan Sustaining Survival yang sudah dicapai dengan terus mengembangkan dan meningkatkan program
CSR yang berfokus pada pendidikan, terutama pendidikan menengah yang sangat dibutuhkan masyarakat menjadi cara yang mudah dan efektif bagi Djarum Foundation, karena sudah teruji berhasil dan sudah memiliki pola yang jelas. Apalagi program Sekolah Kejuruan dapat langsung menyelesaikan masalah tenaga kerja dengan mencetak anak-anak muda mumpuni dalam banyak bidang keahlian.

Setelah 10 bidang keahlian telah dan sedang dijalankan, ke depan Djarum Foundation terus berinovasi dengan akan membuka Sekolah 
Kejuruan baru untuk menambah bidang keahlian yang sudah ada dengan sistem dan konsep yang sama. Pada akhir 2017, bidang keahlian yang akan dibuka, yaitu bidang keahlian Industrial Chemistry (Kimia Industri), Welding (Pengelasan), Hospitality Marketing (Pemasaran Perhotelan), dan Beauty and Spa Therapy (Terapi Kecantikan dan Spa). Kemudian, pada akhir 2018 akan dibuka bidang keahlian yang lain dengan konsep yang sama, yaitu bidang keahlian Furniture and Woodworking, Robotics, Geomatics, dan Agriculture. Total, sampai akhir 2018 akan ada 18 bidang keahlian yang dikembangkan oleh Djarum Foundation dalam program Sekolah Kejuruan.

Strategi komunikasi adalah suatu cara untuk mengatur pelaksanaan proses komunikasi sejak dari perencanaan, pelaksanaan, hingga evaluasi untuk mencapai suatu tujuan. Sebagaimana telah dijelaskan, strategi komunikasi adalah kegiatan atau kampanye komunikasi yang sifatnya informasional maupun persuasif untuk membangun pemahaman dan dukungan terhadap suatu ide, gagasan atau kasus, produk maupun jasa yang terencana yang dilakukan oleh suatu organisasi baik yang berorientasi laba maupun nirlaba, memiliki tujuan, rencana, dan berbagai alternatif berdasarkan riset dan memiliki evaluasi. Program Sekolah Kejuruan sebagai salah satu program tanggung jawab sosial perusahaan (CSR) Djarum Foundation, dirancang sebagai kegiatan yang baik dan bermanfaat bagi masyarakat Indonesia, khususnya warga Kudus tempat berdirinya industri rokokPTDjarum. Setelah melaksanakan programnya dengan kualitas baik yang berstandar internasional, program Sekolah Kejuruan kemudian dipublikasikan dengan baik pula. Hal ini menunjukkan bahwa program Sekolah Kejuruan dijadikan sebagai sebuah konsep strategi komunikasi PT Djarum yang memiliki tujuan tertentu. Dalam hal ini, komunikasi program Sekolah Kejuruan dilakukan secara efektif dengan memilih media, sasaran, isi pesan, dan narasumber yang sesuai dengan program dan produk yang dihasilkannya. Hal ini dilakukan dalam rangka menguatkan posisi strategis Djarum Foundation di level nasional dan internasional. Program Sekolah Kejuruan yang sudah sangat baik tersebut, ternyata juga dipublikasikan kepada stakeholders dan masyarakat umum. Publikasi dilakukan pada level nasional dan internasional. Untuk hal-hal yang menyangkut program yang levelnya nasional, maka dipublikasikan secara lokal dan nasional. Sedangkan untuk yang bersifat internasional, Djarum Foundation mempublikasikannya secara internasional. Dalam konteks CSR industri rokok yang kerap mendapatkan penolakan dan protes, komunikasi program harus dilakukan dengan mempertimbangkan situasi sosial yang sewaktuwaktu merugikan perusahaan.

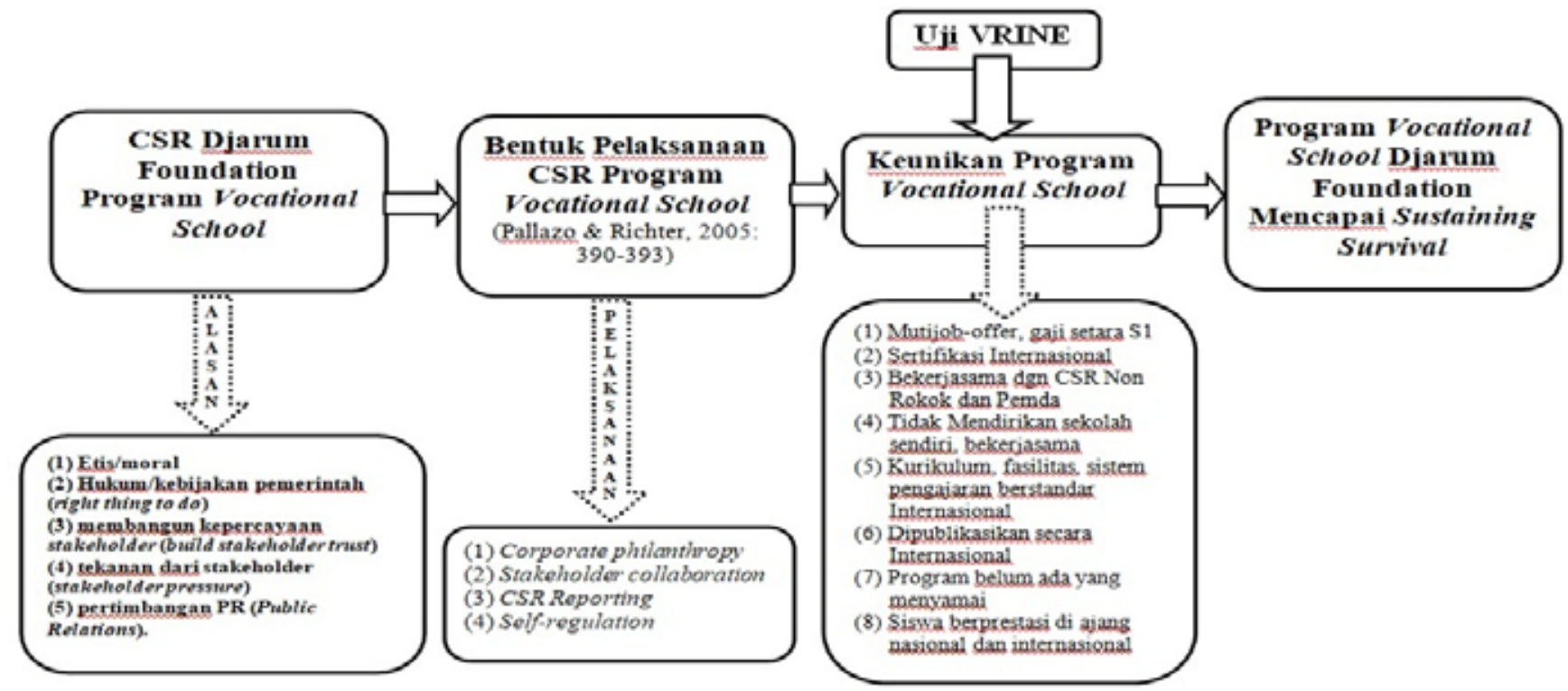

Gambar 1. Posisi, Keunikan, dan Sustaining Survival Program Sekolah Kejuruan Sumber: Hasil Olahan Sendiri 
Jika sekarang keadaan di Kudus normal saja, perusahaan Djarum tetap harus mempersiapkan segala kemunginan buruk dengan cara mengerahkan sumber daya CSR, dalam hal ini Program Sekolah Kejuruan yang sudah dijalankan dengan sangat baik, perlu dikomunikasikan dengan tujuan-tujuan mengantisipasi kemungkinan buruk tersebut. Dalam melaksanakan strategi komunikasinya, Djarum Foundation perlu pula mempertimbangkan harapan-harapan komunitas di Kudus. Karena pada dasarnya strategi komunikasi adalah penentuan pendekatan yang digunakan oleh suatu perusahaan atau organisasi terhadap harapan komunitas sekitar dan bagaimana melaksanakan pendekatan tersebut dengan memanfaatkan sumber daya yang ada sesuai dengan kondisi lingkungannya. Dalam penerapannya Djarum Foundation menerapkan penggunaan konsep media internal dan media eksternal. Media internal yang digunakan sebagai sumber rujukan Djarum Foundation dan program Sekolah Kejuruan adalah website www.djarumfoundation.org dan www. djarumbeasiswaplus.org. Website yang disebut terakhir dikelola oleh satu orang maintenance (eksternal) yang bertugas mengelola semua persoalan teknis website dan satu orang content writer yang bertugas mengisi konten web dalam bentuk tulisan, berupa berita-berita dan informasi lainnya. Selain dua laman website tersebut, ada pula media lain berupa booklet Pengembangan Sekolah Kejuruan.

Strategi komunikasi yang dilakukan oleh Djarum Foundation dengan menggunakan media internal dan eksternal tersebut digunakan untuk menguatkan posisi strategis Djarum Foundation di level nasional dan internasional. Dengan melakukan strategi komunikasi secara terus menerus, maka posisi strategis yang telah dicapai Djarum Foundation tersebut akan tetap terjaga.

PT. Djarum telah melakukan aktivitas produksi rokok di Kabupaten Kudus selama bertahuntahun. Dalam perjalanannya, meskipun industri rokok sudah sejak lama mendapat sorotan negatif karena produknya yang dianggap membahayakan, namun hingga sekarang yang peneliti amati, tidak ada masyarakat Kudus yang memprotes atau menggugat keberadaan pabrik rokok Djarum di Kudus. Namun begitu, PT Djarum harus tetap merawat penerimaan masyarakat Kudus itu dengan berbagai cara, termasuk kegiatan CSR yang peneliti kaji, karena eksistensi perusahaan

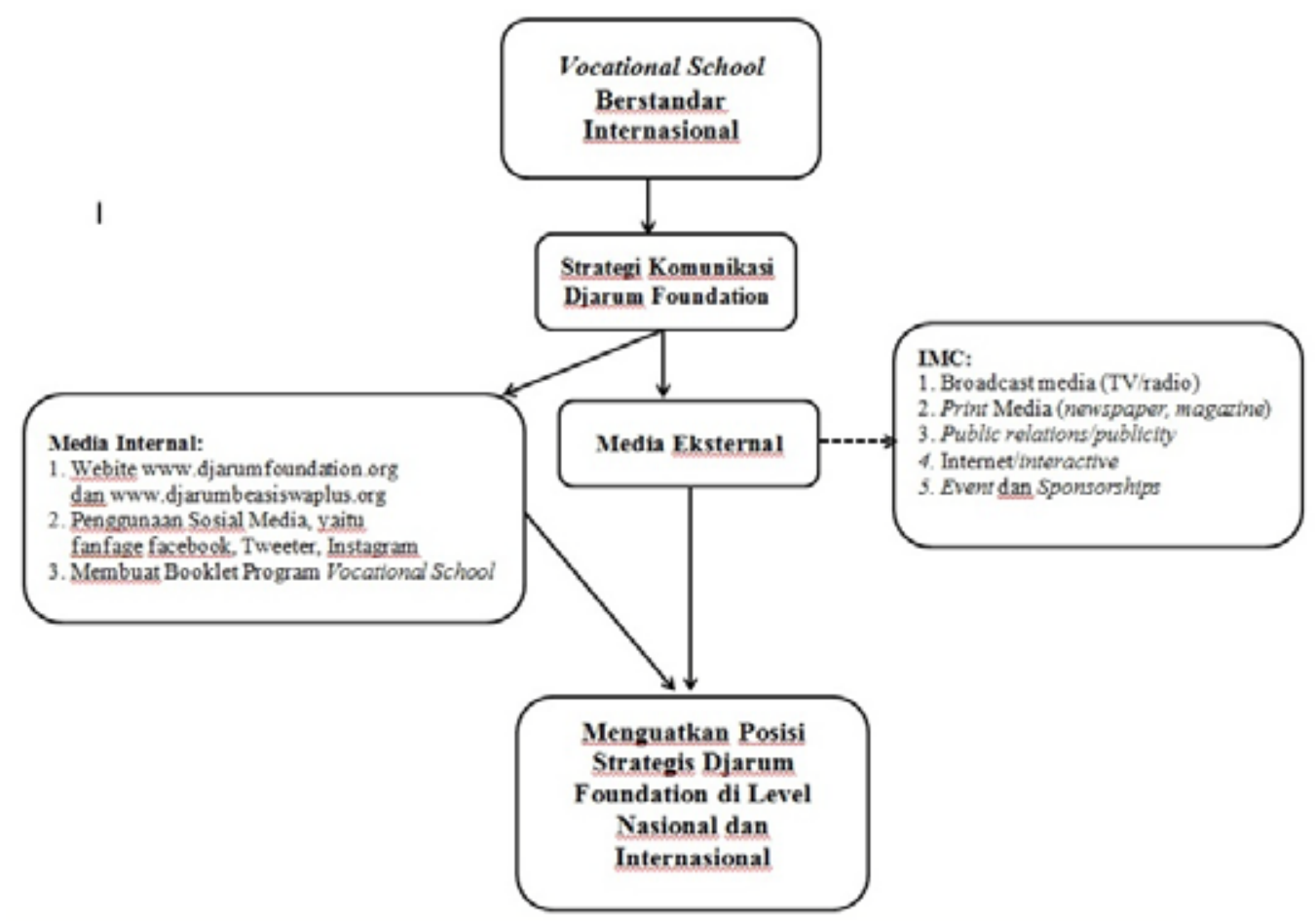

Gambar 2. Strategi Komunikasi Djarum Foundation Sumber: Hasil Olahan Sendiri 
sangat penting bagi kelangsungan dan kelancaran aktivitas bisnis perusahaan. Salah satu program CSR yang dijalankan, yaitu Sekolah Kejuruan telah memperoleh legitimasi masyarakat sebagaimana tercermin dari antusiasme masyarakat terhadap program, implikasi program terhadap peningkatan ekonomi masyarakat Kudus, dan apresiasi pemerintah daerah dan pusat terhadap program Sekolah Kejuruan.

Selain terus berinovasi pada tataran praksis program sekolah kejuruan dan melakukan strategi komunikasi, Djarum Foundation juga melakukan cara lain untuk mendapatkan legitimasi masyarakat, sehingga dengan legitimasi tersebut dapat menguatkan posisi strategis Djarum Foundation. Berdasarkan analisis dengan menggunakan konsep legitimasi yang ditinjau dari beberapa aspek dapat dijelaskan: Pertama, Pragmatic legitimacy. Pragmatic legitimacy diberikan oleh pemangku kepentingan ketika mereka diuntungkan dengan adanya aktivitas perusahaan. Di sini, program Sekolah Kejuruan telah mampu mendorong perekonomian masyarakat, khususnya di Kudus dengan membekali putra-putri daerah tersebut dengan keahlian yang terstandar Internasional. Dengan demikian, perekonomian masyarakat Kudus secara perlahan dapat meningkat seiring dengan munculnya generasi muda berkualitas dan diakui secara internasional dari tahun ke tahun. Sebagaimana telah dijelaskan dalam konsep Piramida Tanggung Jawab Sosial Perusahaan, hal itu terdiri atas empat jenjang tanggung jawab sosial perusahaan yang salah satunya adalah tanggung jawab ekonomi. Dengan mendorong peningkatan ekonomi masyarakat Kudus dari sisi ini, maka PT. Djarum dan Djarum Foundation dapat meraih legitimasi dari masyarakat Kudus, secara khusus dan masyarakat lainnya secara umum.

Kedua, Cognitive legitimacy. Program Sekolah Kejuruan didorong dan dioptimalkan oleh Djarum Foundation di Kudus dalam waktu yang tidak terlalu lama, tapi faktanya sudah mendapatkan respon positif dari masyarakat Kudus, bahkan sudah mampu mengubah paradigma masyarakat Kudus terhadap SMK yang sebelumnya dinilai sebagai 'sekolah buangan', tempat berkumpulnya siswa yang suka tawuran, dan kumpulan calon-calon manusia yang tidak punya masa depan, kemudian menjadi sangat diminati di Kudus dan luar Kudus. Ketiga, Moral legitimacy. Legitimasi moral adalah salah satu komponen penting dalam pelaksanaan Corporate Social Responsibility. Sebuah lembaga CSR selalu memiliki tujuan moral atau etika dalam melaksanakan program tanggung jawab sosialnya.

Program Sekolah Kejuruan dilaksanakan dengan optimal dan berkualitas serta sesuai dengan kebijakan pemerintah. Pemerintah telah menerbitkan Inpres Nomor 9 Tahun 2016 tentang Revitalisasi SMK yang di dalamnya mengandung unsur peningkatan SDM, kurikulum, sertifikasi profesi, pemenuhan sarana-prasarana yang berkualitas, dan Teaching factory. Dari sisi SDM, guru-guru SMK program Sekolah Kejuruan Djarum Foundation secara berkala diberikan kurus-kursus keahlian tertentu untuk meningkatkan kualitasnya, di samping itu, beberapa ahli yang sesuai dengan bidang keahlian Sekolah Kejuruan didatangkan untuk menjadi mentor ahli, sehingga selain ilmu dan pengalamannya bisa terserap secara langsung oleh para siswa, juga dapat menular kepada guru-guru di sana. Kurikulum program Sekolah Kejuruan Djarum Foundation dikembangkan sesuai dengan bidang keahlian dan berstandar internasional dengan mengadopsi kurikulum kejuruan semisal Cisco Networking Academy Program (CNAP) untuk keahlian teknik komputer dan jaringan dan sebagainya. Di samping itu, program Sekolah Kejuruan juga menerapkan sertifikasi yang berstandar internasional sehingga lulusan program ini bisa diakui pada level nasional dan internasional. Dengan dukungan fasilitas yang juga berstandar internasional, SMK program Sekolah Kejuruan Djarum Foundation sesuai dengan langkah-langkah revitalisasi SMK yang dicanangkan pemerintah dalam Inpres Nomor 9 Tahun 2016.

Vivi Adeliana (Wawancara, 20/7/2017) menjelaskan bahwa pelaksanaan peningkatan kualitas SMK yang dijalankan Djarum Foundation, melalui beberapa tahapan yang berkesinambungan, yakni: Penyempurnaan kurikulum untuk disesuaikan dengan kebutuhan industri saat ini; Pelatihan guru dengan menggandeng pakar dan praktisi yang sesuai dengan keahlian jurusan yang tengah dikembangkan; Peningkatan fasilitas dan sarana pembelajaran (infrastuktur) yang sesuai dengan lingkungan dan atmosfer industri; 
Beasiswa; dan Teaching factory. Lebih jauh dari itu, PT Djarum dengan lembaga Djarum Foundationnya yang telah melaksanakan program Corporate Social Responsibility selama bertahun-tahun, telah mendapatkan pengakuan serta penghargaan. Tahun 2010 PT. Djarum mendapat penghargaan "Wahana Lestari" dari Kementerian Kehutanan RI, sebagai konsistensi upaya pelestarian lingkungan selama 30 tahun; tahun 2013 PT Djarum memperoleh penghargaan "KONI Award" atas usaha membina olah raga bulu tangkis nasional; tahun 2016 Global CSR Summit \& Awards 2016 (ajang penghargaan Internasional bergengsi untuk Corporate Social Responsibility) memberikan penghargaan kepada Djarum Foundation untuk kategori Best Environmental Excellence Award (Bronze) dan Excellence in Provision of Literacy \& Education Award (Platinum). (http://csrindonesia.com, 2016). Selain itu, untuk melihat aspek legitimasi, program Sekolah Kejuruan juga perlu dibandingkan dengan Sekolah Kejuruan di daerah lain, khususnya daerah dimana tempat berdirinya perusahaan rokok kompetitor, yaitu Surabaya (PT HM Sampeorna Tbk) dan Kediri (PT Gudang Garam Tbk). Dari perbandingan tersebut, disimpulkan bahwa sekolah kejuruan Djarum Foundation di Kudus, secara kualitas berada di atas sekolah kejuruan yang ada di dua daerah tersebut.

Meskipun Surabaya sudah memiliki sekolah kejuruan yang berstandar internasional, tapi standar internasional yang dimaksud dengan SMK di Surabaya berbeda dengan standar internasional yang diberlakukan pada program Sekolah Kejuruan Djarum Foundation di Kudus. SMK di Surabaya menggunakan standar ISO; sedangkan program Sekolah Kejuruan lebih kepada sertifikasi profesi secara internasional. Kemudian, Sekolah Kejuruan di Surabaya yang berstandar internasional tersebut tidak dibina oleh CSR Sampoerna Foundation (PT. HM Sampoerna Tbk) di mana perusahaan rokok terbesar di Indonesia itu berdiri dan melakukan bisnisnya. Sementara di Kediri, tempat PT. Gudang Garam kompetitor PT. Djarum kedua berdiri, berdasarkan penelusuran peneliti, belum ada Sekolah Kejuruan yang sudah berstandar internasional, hanya baru menerapkan program sekolah berstandar internasional, yaitu Sekolah Menengah Kejuruan Unggulan SMK Negeri 1 Kediri. Kemudian, sejak didirikannya pada
30 April 1986 oleh Michael Bambang Hartono dan Robert Budi Hartono, Djarum Foundation mengusung filosofi "Lahir dari Dalam dan Berkembang Bersama Lingkungan." Filosofi itu mencerminkan kedua pendirinya itu. Artinya, semua program CSR yang dijalankan Djarum Foundation merujuk pada kedua tokoh tersebut. Jika sebuah lembaga melakukan kerja-kerja sosial yang luar biasa, pada dasarnya orang yang ada di balik lembaga itu tentu memiliki kedermawanan sosial yang sifatnya personal yang juga luar biasa.

Program-program CSR Djarum Foundation, tak lepas dari kebijakan dua orang pemilik Djarum. Primadi H. Serad (Wawancara, 18/4/2017) mengatakan, semua program dan kegiatan Djarum Bakti Pendidikan, termasuk program Sekolah Kejuruan dilaksanakan berdasarkan arahan-arahan dari pimpinan. Pemilik PT. Djarum sekaligus pendiri Djarum Foundation memiliki kedermawanan personal atau yang popular disebut sebagai Personal Social Responsibility (PSR). PSR merupakan wujud dari tanggung jawab individu kepada masyarakat karena ia bagian dari masyarakat. Konsep PSR inilah yang menjadi dasar bagi berdirinya lembaga nirlaba Djarum Foundation yang telah melakukan banyak sumbangsih terhadap sosial, dunia olah raga bulu tangkis, lingkungan, budaya, dan pendidikan, termasuk program unggul Sekolah Kejuruan. Sehingga kedermawanan personal dari pendiri Djarum Foundation ini juga dapat memberikan legitimasi dari masyarakat dan menguatkan sustaining survival perusahaan. Dengan hal-hal tersebut, maka dapat dikatakan bahwa Djarum Foundation dapat memperoleh legitimasi masyarakat, khususnya masyarakat Kudus. Legitimasi masyarakat tersebut akan mampu menguatkan posisi strategis Djarum Foundation dan Sustaining Survival perusahaan Djarum. Melalui program Sekolah Kejuruan, Djarum Foundation telah melakukan upayaupaya sistematis dalam rangka menguatkan posisi strategisnya, memperoleh legitimasi masyarakat, dan mencapai Sustaining Survival sekaligus mempertahankannya.

\section{SIMPULAN}

Berdasarkan hasil analisis yang telah dikemukakan, pelaksanaan program Sekolah Kejuruan Djarum Foundation dan strategi 


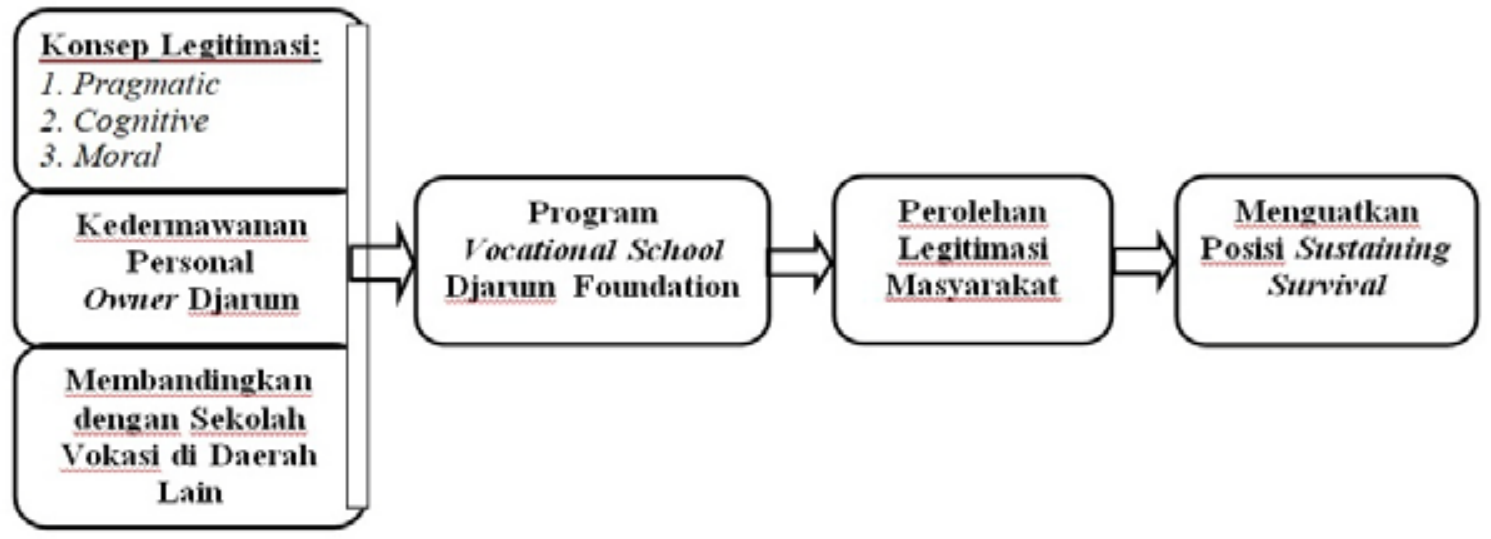

Gambar 3. Perolehan Legitimasi Program Sekolah Kejuruan Sumber: Hasil Olahan Sendiri

komunikasinya, dapat disimpulkan bahwa program Sekolah Kejuruan sudah mencapai Sustaining Survival. Capaian ini akan bertahan lama, karena lembaga lain tidak akan mudah untuk meniru program tersebut. Djarum Foundation terus berupaya mempertahankan Sustaining Survival yang sudah dicapai dengan terus mengembangkan dan meningkatkan program CSR yang berfokus pada pendidikan, terutama pendidikan menengah kejuruan yang sangat dibutuhkan masyarakat, apalagi program sekolah ini dapat langsung menyelesaikan masalah tenaga kerja dengan mencetak anak-anak muda mumpuni dalam banyak bidang keahlian. Program Sekolah Kejuruan yang berstandar internasional, ternyata juga dipublikasikan kepada stakeholders dan masyarakat umum secara nasional dan internasional. Semua upaya publikasi tersebut dilaksanakan dengan menggunakan strategi komunikasi.

Selain terus berinovasi pada tataran praksis program Sekolah Kejuruan dan melakukan strategi komunikasi, Djarum Foundation juga melakukan cara lain untuk mendapatkan legitimasi masyarakat, sehingga dengan legitimasi tersebut dapat menguatkan posisi strategis Djarum Foundation. Ringkasnya, melalui program Sekolah Kejuruan, Djarum Foundation telah melakukan upaya-upaya sistematis dalam rangka menguatkan posisi strategisnya, memperoleh legitimasi masyarakat, dan mencapai Sustaining Survival sekaligus mempertahankannya.

\section{DAFTAR PUSTAKA}

Carroll, A.B. 1991. "The Pyramid of Corporate Social Responsibility: Toward the Moral

Management of Organizational Stakeholders." Business Horizons. Edisi Juli-Agustus, pp. 39-48.

Daymon, Christine and Holloway, Immy. 2008. Qualitative Research Method in Public

Relation and Marketing Communication. Saduran Cahya Wiratama. Penerbit Bentang. Yogyakarta.

Ekawati, TheresiaJuwita.2012."Strategi Corporate Social Responsibility Berdasarkan

Resources Based Theory (Studi Kasus: Djarum Foundation)". Tesis. Universitas Indonesia. Jakarta.

Ganiem, Ambadar, dan Sukardjo. 2015. PSR (Personal Social Responsibility); Aku, Kamu, Kita Bisa. Kencana. Jakarta.

Hadam, Sampun, Rahayu, Nastiti, dan Ariyadi, Ayu Nur. 2017. Strategi Implementasi

Revitalisasi SMK (10 Langkah Revitalisasi SMK). Penerbit Direktorat Pembinaan SMK Ditjen Pendidikan Dasar dan Menengah Kementerian Pendidikan dan Kebudayaan. Jakarta.

Hardjana, Andre A. 2008. "Komunikasi dalam Manajemen Reputasi Korporasi." Jurnal Komunikasi Vol. 5 No. 1, pp. 1-24. 
Ingratubun, Adrian. 2017. "Strategi Progresif CSR Perseroan Indosiar dalam Meraih

Penghargaan Asia Responsibility Entrepreneurship Award." Jurnal Wacana, Volume 16. No. 1, Juni 2017, hlm 84-101.

Kotler, Phillip and Lee, Nancy. 2005. Corporate Social Responsibilty: Doing the Most Good for Your Company and Your Cause. John Wiley and Son, Inc. New Jersey.

Mc Williams, A., and Siegel, D. 2001. "Corporate Social Responsibility: A Theory of the

Firm Perspective," Academy of Management Review. Vol. 26: 117-27.

Pallazo, Guide and Richter, Ulf. 2005. "CSR Busi- ness as Usual? The Case of Tobacco

Industry." Journal of Business Ethics, 61, pp: 387401.

Restiyanti, Marissa. 2016. "Strategi Periklanan dalam Promosi Program Bollystar Vaganza di

ANTV." Jurnal Wacana, Volume XV. No. 2. Juni 2016, hlm. 86-180.

Sabini, Marselinus Nuba dan Ganiem, Leila Mona. 2015. "Corporate Social Responsibility Sebagai Strategi Komunikasi Bisnis Perusahaan." Jurnal Komunikasi ASPIKOM, Volume 2. Nomor 5, Juli 2015, hlm 346-356. 